\title{
Strong Gender-Specific Additive Effects of the NYD-SP18 and FTO Variants on BMI Values
}

\author{
J. A. HUBACEK ${ }^{1}$, D. DLOUHA ${ }^{2}$, V. LANSKA ${ }^{2}$, V. ADAMKOVA ${ }^{3}$ \\ ${ }^{1}$ Center for Experimental Medicine, Institute for Clinical and Experimental Medicine, Prague, \\ Czech Republic, ${ }^{2}$ Statistical Unit, Institute for Clinical and Experimental Medicine, Prague, Czech \\ Republic, ${ }^{3}$ Department of Preventive Cardiology, Center for Experimental Medicine, Institute for \\ Clinical and Experimental Medicine, Prague, Czech Republic
}

Received July 17, 2015

Accepted July 31, 2015

\section{Summary}

The role of the FTO gene in obesity development is well established in populations around the world. The NYD-SP18 variant has been suggested to have a similar effect on BMI, but the role of this gene in determining BMI has not yet been verified. The objective of our study was to confirm the association between NYD-SP18 rs6971019 SNP and BMI in the Slavic population and to analyze i) the gender-specific effects of NYD-SP18 on BMI and ii) the simultaneous effect of FTO rs17817449 and NYD-SP18 on BMI. We analyzed a sample of a large adult population based on the post-MONICA study (1,191 males and 1,368 females). Individuals were analyzed three times over 9 years. NYD-SP18 rs6971019 SNP is related to BMI in males $\left(2000 / 1 \mathrm{GG} 28.3 \pm 3.7 \mathrm{~kg} / \mathrm{m}^{2}\right.$ vs. + A $27.5 \pm 3.7 \mathrm{~kg} / \mathrm{m}^{2}$ $\mathrm{P}<0.0005$; in other examinations $\mathrm{P}<0.05$ and $<0.005$ ), but not in females (all $P$ values over 0.48 in all three examinations). Further analysis revealed the significant additive effect (but not the interaction) of FTO and NYD-SP18 SNPS on BMI in males (all $\mathrm{P}<0.01$ ). These results suggest that association between NYD-SP18 rs6971019 SNP and BMI may be restricted to males. Furthermore, variants within NYD-SP18 and FTO genes revealed a significant additive effect on BMI values in males.

\section{Key words}

FTO • NYD-SP18・BMI • Polymorphism

\section{Corresponding author}

J. A. Hubacek, IKEM-CEM-LMG, Videnska 1958/9, 14021 Prague 4, Czech Republic. E-mail: jahb@ikem.cz

\section{Introduction}

Obesity is one of the serious non-communicable diseases, which further increases the risk of cardiovascular diseases, cancer and diabetes development. In the most affected populations, about $60 \%$ of individuals are overweight or obese and prevalence of obesity is significantly increasing even in children (Pastucha et al. 2013, Vrablik et al. 2014). Generally, overweight and obesity result from a positive energy balance, caused by the combination of low physical activity and high-energy intake. However, "nontraditional" factors like sleeping deficits, side effects of commonly prescribed drugs (mainly insulin, hypertensives, hormonal contraceptives) or social factors can significantly contribute and should not be omitted (Hubacek 2009, Adamkova et al. 2009, McAllister et al. 2009).

Body weight/body mass index (BMI) is also significantly influenced by genetic factors. Twin studies have estimated that genetic factors can be responsible for even about $60 \%$ of body mass index (BMI) variability. However, despite intensive efforts in recent decades, BMI heritability is still poorly understood and remains hidden within the context of concrete genes and variants.

Using the genome-wide analysis approach, two genes (among others), with largely unknown mechanisms by which they may influence the risk of obesity development, have been detected - FTO and NYD-SP18.

The association between BMI and FTO ("fat mass and obesity-associated gene") was discovered by 
many groups simultaneously (Dina et al. 2007, Frayling et al. 2007, Scuteri et al. 2007). FTO has a potential to demethylate DNA (Gerken et al. 2007) and function as a possible transcriptional cofactors (Wu et al. 2010). To date, the general consensus is that FTO variants within the first intron are the strongest determinants of BMI among different ethnic groups around the world (reviewed by Cheung and Yeo 2010, Dlouha and Hubacek 2014). The association between rs17817449 SNP and BMI has also been confirmed in the Czech population (Hubacek et al. 2009, Dušátková et al. 2013). However, studies that have focused on the functional association between FTO and BMI reveal no clear results. Thus, it is not completely clear whether FTO affects BMI through its effect on physical activity, basal metabolism or energy intake (Berentzen et al. 2008, Cecil et al. 2008, Haupt et al. 2009, Hubacek et al. 2011, Liu et al. 2010, Harbron et al. 2014).

In contrast, NYD-SP18 (a protein with a largely unknown function except for its role in testes development via its influence on circulating testosterone levels) has been identified using fine mapping of the region on chromosome 7 , widely known for its high LOD score for obesity. In an original study (the NHLBI Family Heart Study; replicated in the Framingham study), the effect of the NYD-SP18 rs6971091 variant on BMI was even larger than the effect of the widely-analyzed $1 \mathrm{st}$ intron FTO variants (Wilk et al. 2008). However, the effect of NYD-SP18 on BMI was never confirmed or disproved in later studies.

The aim of our study was to confirm the original finding of the association between NYD-SP18 and BMI and to analyze the possible FTO - NYD-SP18 interaction in determining BMI.

\section{Materials and Methods}

Analyzed subjects

We analyzed NYD-SP18 SNP rs6971091 in a group of representatively and randomly selected adult individuals with the known FTO genotype, rs17817449 (1,191 males and 1,368 females, aged 25-64 years at the age of first examination; mean age of $49.0 \pm 10.7$ years) (Hubacek et al. 2009, 2015). The individuals had participated in the post-MONICA study (Cifkova et al. 2010). The WHO MONICA Project protocol (TunstallPedoe et al. 2003) was aligned to examine risk factors of cardiovascular disease development, including BMI and WHR. The subjects were examined in 9 Czech districts
(Kromeriz, Chrudim, Cheb, Jindrichuv Hradec, Pardubice, Litomerice, Plzen, Prague East, and Benesov) in 1997/1998 and were completely re-examined in 2000/2001 (cohort from 2000/2001) and mostly (95.1\%) also in $2007 / 8$. Written, informed consent was given by all individuals. The study was approved by the institute's Ethics Committee at the Institute for Clinical and Experimental Medicine, Prague and is in agreement with the Helsinki Declaration of 1975.

\section{Genotyping}

Genomic DNA was extracted from peripheral blood white cells using a standard salting-out method (Miller et al. 1988).

NYD-SP18 SNP rs6971091 was genotyped using the PCR-RFLP technique. All PCR chemicals were obtained from Fermentas International Inc., Burlington, Ontario, Canada and PCR reactions were performed on a PCR device - DYAD Disciple (MJ Research). Briefly, DNA was amplified in a total volume of $25 \mu \mathrm{l}$ with the oligonucleotides, 5' aag gcc tta acc acc tgg ttc tgc and 5 ' cet tgg tca tta get gaa tga gaa gct. The final PCR product (105 bp) was cut with 5 units of the restriction enzyme, HindIII (Fermentas International Inc., Burlington, Ontario, Canada) and restriction fragments were separated on $10 \%$ polyacrylamide gel using the MADGE platform (Day et al. 1996). Restriction fragments, $26 \mathrm{bp}$ and $79 \mathrm{bp}$, represented the minor A-allele, while the presence of the uncut product represented the major G-allele.

FTO SNP rs17817449 has already been analyzed in more detail, as described previously (Hubacek et al. 2008, 2009).

\section{Statistical analysis}

Deviations in Hardy-Weinberg equilibrium were tested using the following link: http://www.tufts.edu/ mcourt01/Documents/Court\%201a b\%20-\%20HW\%20calculator.xls.

ANOVA was used for statistical analyses. Males and females were analyzed separately. For individual gene analyses, we pooled minor AA homozygotes $(7.2 \%)$ and GA heterozygotes together because of the relative low frequency of the minor A-allele of rs6971019 homozygotes. A P value of 0.05 was defined as significant.

We analyzed the simultaneous effect of the NYD-SP18 and FTO variants in three subgroups defined by the presence of different numbers of risky alleles 
(G for FTO rs17817449 and G for NYD-SP18 rs6971091) - allele combinations of three and more, exactly two, or less than two. For this analysis, only men with records of both genotypes and BMI at all three examinations were included $(\mathrm{N}=1,034)$.

\section{Results}

Basic characteristics of examined individuals at the 2000/2001 examination are presented in Table 1 .

Table 1. Baseline characteristics for individuals analyzed in 2000/2001.

\begin{tabular}{lcc}
\hline & $\begin{array}{c}\text { Post-MONICA } \\
\text { Males }\end{array}$ & $\begin{array}{c}\text { Post-MONICA } \\
\text { Females }\end{array}$ \\
\hline$N$ & 1,191 & 1,368 \\
Age (years) & $49.2 \pm 10.8$ & $48.8 \pm 10.6$ \\
BMI (kg/m $\left.{ }^{2}\right)$ & $28.2 \pm 4.0$ & $27.6 \pm 5.5$ \\
WHR & $0.929 \pm 0.064$ & $0.810 \pm 0.072$ \\
$\begin{array}{l}\text { Cholesterol } \\
\text { (mmol/l) }\end{array}$ & $5.75 \pm 1.06$ & $5.80 \pm 1.15$ \\
$\begin{array}{l}\text { Triglycerides } \\
\text { (mmol/l) }\end{array}$ & $1.98 \pm 1.28$ & $1.46 \pm 0.85$ \\
$\begin{array}{l}\text { HDL-cholesterol } \\
\text { (mmol/l) }\end{array}$ & $1.26 \pm 0.33$ & $1.50 \pm 0.36$ \\
$\begin{array}{l}\text { Diabetes (\%) } \\
\text { Hypertension (\%) }\end{array}$ & 6.0 & 4.4 \\
$\begin{array}{l}\text { Smoking } \\
\text { prevalence (\%) }\end{array}$ & 32.7 & 33.4 \\
\hline
\end{tabular}

Call rates (calculated for individuals examined in 1998/9 and 2000/1, respectively) were $96.4 \%$ for FTO and $97.8 \%$ for NYD-SP18 SNPs.

Distributions of individual genotypes were in Hardy-Weinberg equilibrium. Frequencies of the individual alleles and genotypes were similar to the frequencies observed in other Caucasian populations (for example Dina et al. 2007, Frayling et al. 2007, Scuteri et al. 2007, Dušátková et al. 2013, Wilk et al. 2008).

As described before in the Czech post-MONICA population study, we detected a significant association $(\mathrm{P}<0.02)$ between FTO genotypes and BMI in males in cases where a co-dominant model of analysis was used (Table 2). In females, the effect progressed in the same direction but the observed differences did not reach statistical significance (Hubacek et al. 2009), which suggests that age or menopausal status in females is a significant determining confounder of BMI through the FTO gene. Results for females were similar in all three examinations.

Furthermore, similar gender-specific results were also obtained in the case of the NYD-SP18 polymorphism. We confirmed the findings from the original study (Wilk et al. 2008) in males only and detected higher BMI values in NYD-SP18 GG homozygotes than in A-allele carriers (GG 28.3 \pm 3.7 $\mathrm{kg} / \mathrm{m}^{2}$ vs. $\left.+\mathrm{A} \quad 27.5 \pm 3.7 \mathrm{~kg} / \mathrm{m}^{2} ; \quad \mathrm{P}<0.0005\right)$. Similar significant differences were observed in both other examinations $(\mathrm{P}<0.05$ and $<0.005$, respectively $)$ (Table 2). In females, no effect of rs6971091 within the NYD-SP18 gene on BMI values in any of the three examinations was observed (all $\mathrm{P}$ values over 0.48; results are not shown in detail).

Table 2. Genotype frequencies of analyzed individuals and the association between FTO rs17817449 and NYD-SP18 rs6971019 polymorphisms and BMI values $\left(\mathrm{kg} / \mathrm{m}^{2}\right)$ in the Czech postMONICA study of $2000 / 2001$.

\begin{tabular}{lcccc}
\hline rs17817449 & $\mathbf{N}$ & $\mathbf{\%}$ & $\mathbf{B M I}$ & $\mathbf{p}$ \\
\hline Males & & & & \\
\hline$G G$ & 177 & 15.9 & $28.7 \pm 3.7$ & \\
$G T$ & 572 & 51.4 & $28.3 \pm 4.1$ & 0.014 \\
$T T$ & 364 & 32.7 & $27.8 \pm 3.9$ & \\
\hline Females & & & & \\
\hline GG & 249 & 18.4 & $27.9 \pm 5.7$ & \\
GT & 652 & 48.1 & $27.5 \pm 5.4$ & n.s. \\
$T T$ & 453 & 33.5 & $27.4 \pm 5.0$ & \\
\hline rs6971019 & $\mathbf{N}$ & $\mathbf{6}$ & $\mathbf{B M I}$ & $\mathbf{p}$ \\
\hline Males & & & & \\
\hline GG & & & & \\
+ A & 630 & 53.6 & $28.3 \pm 3.7$ & 0.0005 \\
\hline Females & 545 & 46.4 & $27.5 \pm 3.6$ & \\
\hline GG & & & & \\
+ A & 696 & 52.4 & $27.4 \pm 5.3$ & n.s. \\
\hline
\end{tabular}

In males, we further analyzed whether the combination between the FTO rs17817449 and NYD-SP18 rs6971091 polymorphisms had an influence on BMI or whether it had an additive effect, or whether these SNPs exhibited any interaction. Distinct combinations, based on the number of risky alleles of 
FTO and NYD-SP18 SNPs, revealed a significant effect on BMI in the additive model (all three $\mathrm{P}$ values were over 0.004; all three analyses remained significant after Bonferroni correction for multiple testing). However, no interaction (all three $\mathrm{P}$ values were over 0.56 ) between the analyzed SNPs was found (Table 3). Briefly, carriers of at least three risky alleles had the highest BMI values and carriers of at least three protective alleles had the lowest, with carriers of exactly two risky and two protective alleles exhibiting medium values $(\mathrm{P}<0.0001$ in 2000/2001; for more details see Table 3). Adjustment for age did not change the differences significantly.

Table 3. Additive effects of the FTO $\mathrm{rs} 17817449$ and NYD-SP18 $\mathrm{rs} 6971019$ polymorphisms on BMI $\left(\mathrm{kg} / \mathrm{m}^{2}\right)$ in males from the $2000 / 2001$ Czech post-MONICA study, according to subgroups with different numbers of risky alleles.

\begin{tabular}{llll}
\hline FTO/NYD-SP18 genotypes & N & BMI & P< \\
\hline$G G / G G$ and $G G / G A$ and $G T / G G$ & 393 & $28.8 \pm 4.1$ & 0.0001 \\
$G G / A A$ and $T T / G G$ and $G T / G A$ & 442 & $27.9 \pm 3.9$ & \\
\hline$T T / A A$ and $T T / G A$ and $T T / A A$ & 199 & $27.3 \pm 3.9$ & \\
\hline
\end{tabular}

\section{Discussion}

Body weight is a polygenic trait, which means that many variants within dozens of genes can significantly affect final individual values (Day and Loos 2011). It is estimated that single negative alleles increase body weight to a maximum of about one kilogram (FTO, NYD-SP18 genes). However, most of the risky alleles add about 200-300 g "only". Some studies have focused on gene score in the context of BMI association (Peterson et al. 2011, Domingue et al. 2014). However, knowledge is sparse in the following areas: simultaneous presence of more risky alleles; additive effects and interaction; the critical number of risky alleles that leads to obesity in all cases; and at what stage alleles appear.

In our study, we analyzed the simultaneous effect of the two major BMI determinants, namely the genes for FTO and NYD-SP18. Briefly, we confirmed that the simultaneous presence of the distinct alleles of these genes is associated with enhanced BMI values. Importantly, we detected that there is a significant gender-specific effect of these genes on BMI. We also found a significant association between the variants of these genes and BMI in males only.

Dozens of papers have confirmed the role of the FTO gene in genetic determination of obesity (Hubacek et al. 2008, Dušátková et al. 2013, Tönjes et al. 2010, Hakanen et al. 2009) and many studies have focused on similar topics, e.g. determination of body mass changes after life style interventions (Dlouha et al. 2011, Schum et al. 2012, Zlatohlavek et al. 2014, Reinehr et al. 2014). Finally, the FTO gene has also been associated with enhanced risk of cardiovascular disease (Hubacek et al.
2010, Doney et al. 2009), renal failure (Hubacek et al. 2012), type 2 diabetes (Scott et al. 2007), Alzheimer's disease (Reitz et al. 2012), suicide (Chojnicka et al. 2014) and even with infection diseases, such as tuberculosis (Feng et al. 2014).

In relative contrast to the well-established role of $F T O$, our study is the first to confirm the role of the NYD-SP18 rs6971091 polymorphism in BMI determination, as suggested by Wilk et al. (2008). Furthermore, we have recently presented data suggesting that this gene could be a significant predictor of body composition changes in adult females after intensive tenweek life-style interventions, based on intensive physical activity and age-adjusted optimal energy intake (Suchanek et al. 2015). This finding is of interest mainly because BMI is not strongly affected by this variant at the female population level.

Interestingly, in both genes, details in relation to the mechanism of action are unclear. It has been suggested that FTO first intron variants may have effects on epigenetic changes (Almén et al. 2012), transcriptional activity (Wu et al. 2010), RNA modification (Berulava et al. 2013) and leukocyte telomere length (Dlouha et al. 2012), which, surprisingly, point to some very heterogeneous regulatory effects. The function of the NYD-SP18 gene is largely unknown, although it has been suggested that it may influence testosterone production.

The major limitation of our study is that we did not have a confirmatory group of individuals at our disposal. However, our subjects were examined three times within the nine-year period, of which all analyses led to identical conclusions, thus lowering the risk of false-positive results. 
We conclude that the NYD-SP18 rs6971091 polymorphism could be a significant genetic determinant of BMI values in males, but not in females. Furthermore, we observed an additive effect on BMI between the FTO rs17817449 and NYD-SP18 rs697109 genetic variants in males, which underlines the importance of the simultaneous context-dependent analyses of variants in multiple genes.

\section{Conflict of Interest}

There is no conflict of interest.

\section{Acknowledgements}

The study was supported by the project (Ministry of Health, Czech Republic) for development of research organization 00023001 (Institute for Clinical and Experimental Medicine, Prague, Czech Republic) institutional support.

\section{References}

ADÁMKOVÁ V, HUBÁCEK JA, LÁNSKÁ V, VRABLÍK M, KRÁLOVÁ LESNÁ I, SUCHÁNEK P, ZIMMELOVÁ P, VELEMINSKÝ M: Association between duration of the sleep and body weight. Physiol Res $\mathbf{5 8}$ (Suppl 1): S27-S31, 2009.

ARMÉN MS, JACOBSON JA, MOSCHONIS G, BENEDIKT C, CHROUSOS GP, FREDERICKSSON R, SCHIÖTH HB: Genome wide analysis reveals association of a FTO gene variant with epigenetic changes. Genomics 99: 132-137, 2012.

BERENTZEN T, KRING SI, HOLST C, ZIMMERMANN E, JESS T, HANSEN T, PEDERSEN O, TOUBRO S, ASTRUP A, SØRENSEN TI: Lack of association of fatness-related FTO gene variants with energy expenditure or physical activity. J Clin Endocrinol Metab 93: 2904-2908, 2008.

BERULAVA T, ZIEHE M, KLEIN-HITPASS L, MLADENOV E, THOMALE J, RÜTHER U, HORSTHEMKE B: FTO levels affect RNA modification and the transcriptome. Eur J Hum Genet 21: 317-323, 2013.

CECIL JE, TAVENDALE R, WATT P, HETHERINGTON MM, PALMER CN: An obesity-associated FTO gene variant and increased energy intake in children. N Engl J Med 359: 2558-2566, 2008.

CHEUNG MK, YEO GS: FTO biology and obesity: Why do a billion of us weigh $3 \mathrm{~kg}$ more? Front Endocrinol (Lausanne) 2: 4, 2011.

CHOJNICKA I, FUDALEJ S, WALCZAK A, WASILEWSKA K, FUDALEJ M, STAWIŃSKI P, STRAWA K, PAWLAK A, WOJNAR M, KRAJEWSKI P, PŁOSKI R: Inverse association between obesity predisposing FTO genotype and completed suicide. PLoS One 9: e108900, 2014.

CÍFKOVÁ R, SKODOVÁ Z, BRUTHANS J, ADÁMKOVÁ V, JOZÍFOVÁ M, GALOVCOVÁ M, WOHLFAHRT P, KRAJCOVIECHOVÁ A, POLEDNE R, STÁVEK P, LÁNSKÁ V: Longitudinal trends in major cardiovascular risk factors in the Czech population between 1985 and 2007/8. Czech MONICA and Czech post-MONICA. Atherosclerosis 211: 676-681, 2010.

DAY IN, BOLLA M, HADDAD L, O'DELL S, HUMPHRIES SE: Microtiter Array Diagonal Gel Electrophoresis (MADGE) for population scale genotype analyses. Methods Mol Med 5: 269-281, 1996.

DAY FR, LOOS RJ: Developments in obesity genetics in the era of genome-wide association studies. $J$ Nutrigenet Nutrigenomics 4: 222-238, 2011.

DINA C, MEYRE D, GALLINA S, DURAND E, KÖRNER A, JACOBSON P, CARLSSON LM, KIESS W, VATIN V, LECOEUR C, DELPLANQUE J, VAILLANT E, PATTOU F, RUIZ J, WEILL J, LEVY-MARCHAL C, HORBER F, POTOCZNA N, HERCBERG S, LE STUNFF C, BOUGNĖRES P, KOVACS P, MARRE M, BALKAU B, CAUCHI S, CHÈVRE JC, FROGUEL P: Variation in FTO contributes to childhood obesity and severe adult obesity. Nat Genet 39: 724-726, 2007. Corrigendum: Nat Genet 39: 1285, 2007.

DLOUHÁ D, HUBÁČEK JA: FTO gene and his role in genetic determination of obesity (in Czech). Vnitr Lek 58: 208-215, 2012.

DLOUHÁ D, SUCHÁNEK P, LÁNSKÁ V, HUBÁČEK JA: Body mass index change in females after short-time life style intervention is not dependent on the FTO polymorphisms. Physiol Res 60: 199-202, 2011.

DLOUHA D, PITHA J, LANSKA V, HUBACEK JA: Association between FTO 1st intron tagging variant and telomere length in middle aged females. 3PMFs study. Clin Chim Acta 413: 1222-1225, 2012. 
DOMINGUE BW, BELSKY DW, HARRIS KM, SMOLEN A, MCQUEEN MB, BOARDMAN JD: Polygenic risk predicts obesity in both white and black young adults. PLoS One 9: e101596, 2014.

DONEY AS, DANNFALD J, KIMBER CH, DONNELLY LA, PEARSON E, MORRIS AD, PALMER CN: The FTO gene is associated with an atherogenic lipid profile and myocardial infarction in patients with type 2 diabetes: a Genetics of Diabetes Audit and Research Study in Tayside Scotland (Go-DARTS) study. Circ Cardiovasc Genet 2: 255-259, 2009.

DUŠÁTKOVÁ L, ZAMRAZILOVÁ H, SEDLÁČKOVÁ B, VČELÁK J, HLAVATÝ P, ALDHOON HAINEROVÁ I, KORENKOVÁ V, BRADNOVÁ O, BENDLOVÁ B, KUNEŠOVÁ M, HAINER V: Association of obesity susceptibility gene variants with metabolic syndrome and related traits in 1,443 Czech adolescents. Folia Biol (Praha) 59: 123-133, 2013.

FENG Y, WANG F, PAN H, QIU S, LÜ J, WU L, WANG J, LU C: Obesity-associated gene FTO rs9939609 polymorphism in relation to the risk of tuberculosis. BMC Infect Dis 14: 592, 2014.

FRAYLING TM, TIMPSON NJ, WEEDON MN, ZEGGINI E, FREATHY RM, LINDGREN CM, PERRY JR, ELLIOTT KS, LANGO H, RAYNER NW, SHIELDS B, HARRIES LW, BARRETT JC, ELLARD S, GROVES CJ, KNIGHT B, PATCH AM, NESS AR, EBRAHIM S, LAWLOR DA, RING SM, BENSHLOMO Y, JARVELIN MR, SOVIO U, BENNETT AJ, MELZER D, FERRUCCI L, LOOS RJ, BARROSO I, WAREHAM NJ, KARPE F, OWEN KR, CARDON LR, WALKER M, HITMAN GA, PALMER CN, DONEY AS, MORRIS AD, SMITH GD, HATTERSLEY AT, MCCARTHY MI: A common variant in the FTO gene is associated with body mass index and predisposes to childhood and adult obesity. Science 316: 889-894, 2007.

GERKEN T, GIRARD CA, TUNG YC, WEBBY CJ, SAUDEK V, HEWITSON KS, YEO GS, MCDONOUGH MA, CUNLIFFE S, MCNEILL LA, GALVANOVSKIS J, RORSMAN P, ROBINS P, PRIEUR X, COLL AP, MA M, JOVANOVIC Z, FAROOQI IS, SEDGWICK B, BARROSO I, LINDAHL T, PONTING CP, ASHCROFT FM, O'RAHILLY S, SCHOFIELD CJ: The obesity-associated FTO gene encodes a 2-oxoglutarate-dependent nucleic acid demethylase. Science 318: 1469-1472, 2007.

HAKANEN M, RAITAKARI OT, LEHTIMÄKI T, PELTONEN N, PAHKALA K, SILLANMÄKI L, PELTONEN N, PAHKALA K, SILLANMÄKI L, LAGSTRÖM H, VIIKARI J, SIMELL O, RÖNNEMAA T: FTO genotype is associated with body mass index after the age of seven years but not with energy intake or leisure-time physical activity. J Clin Endocrinol Metab 94: 1281-1287, 2009.

HARBRON J, VAN DER MERWE L, ZAAHL MG, KOTZE MJ, SENEKAL M: Fat mass and obesity-associated (FTO) gene polymorphisms are associated with physical activity, food intake, eating behaviors, psychological health, and modeled change in body mass index in overweight/obese Caucasian adults. Nutrients 6: 3130-3152, 2014.

HAUPT A, THAMER C, STAIGER H, TSCHRITTER O, KIRCHHOFF K, MACHICAO F, HÄRING HU, STEFAN N, FRITSCHE A: Variation in the FTO gene influences food intake but not energy expenditure. Exp Clin Endocrinol Diabetes 117: 194-197, 2009.

HUBACEK JA: Eat less and exercise more - is it really enough to knock down the obesity pandemia? Physiol Res $\mathbf{5 8}$ (Suppl 1): S1-S6, 2009.

HUBACEK JA, BOHUSLAVOVA R, KUTHANOVA L, KUBINOVA R, PEASEY A, PIKHART H, MARMOT MG, BOBAK M: The FTO gene and obesity in a large Eastern European population sample: the HAPIEE study. Obesity (Silver Spring) 16: 2764-2766, 2008.

HUBACEK JA, PITHA J, ADAMKOVA V, LANSKA V, POLEDNE R: A common variant in the FTO gene is associated with body mass index in males and postmenopausal females but not in premenopausal females. Czech post-MONICA and 3PMFs studies. Clin Chem Lab Med 47: 387-390, 2009.

HUBACEK JA, STANEK V, GEBAUEROVÁ M, PILIPCINCOVÁ A, DLOUHÁ D, POLEDNE R, ASCHERMANN M, SKALICKÁ H, MATOUSKOVÁ J, KRUGER A, PENICKA M, HRABÁKOVÁ H, VESELKA J, HÁJEK P, LÁNSKÁ V, ADÁMKOVÁ V, PITHA J: A FTO variant and risk of acute coronary syndrome. Clin Chim Acta 411: 1069-1072, 2010.

HUBÁČEK JA, PIKHART H, PEASEY A, KUBÍNOVÁ R, BOBÁK M: FTO variant, energy intake, physical activity and basal metabolic rate in Caucasians. The HAPIEE study. Physiol Res 60: 175-183, 2011. 
HUBACEK JA, VIKLICKY O, DLOUHA D, BLOUDICKOVA S, KUBINOVA R, PEASEY A, PIKHART H, ADAMKOVA V, BRABCOVA I, POKORNA E, BOBAK M: The FTO gene polymorphism is associated with end-stage renal disease: two large independent case-control studies in a general population. Nephrol Dial Transplant 27: 1030-1035, 2012.

HUBACEK JA, STANEK V, GEBAUEROVA M, POLEDNE R, ASCHERMANN M, SKALICKA H, MATOUSKOVA J, KRUGER A, PENICKA M, HRABAKOVA H, VESELKA J, HAJEK P, LANSKA V, ADAMKOVA V, PITHA J: Rs6922269 marker at the MTHFD1L gene predict cardiovascular mortality in males after acute coronary syndrome. Mol Biol Rep 42: 1289-1293, 2015.

LIU G, ZHU H, LAGOU V, GUTIN B, STALLMANN-JORGENSEN IS, TREIBER FA, DONG Y, SNIEDER H: FTO variant rs9939609 is associated with body mass index and waist circumference, but not with energy intake or physical activity in European- and African-American youth. BMC Med Genet 11: 57, 2010.

MCALLISTER EJ, DHURANDHAR NV, KEITH SW, ARONNE LJ, BARGER J, BASKIN M, BENCA RM, BIGGIO J, BOGGIANO MM, EISENMANN JC, ELOBEID M, FONTAINE KR, GLUCKMAN P, HANLON EC, KATZMARZYK P, PIETROBELLI A, REDDEN DT, RUDEN DM, WANG C, WATERLAND RA, WRIGHT SM, ALLISON DB: Ten putative contributors to the obesity epidemic. Crit Rev Food Sci Nutr 49: 868-913, 2009.

MILLER SA, DYKES DD, POLESKY HF: A simple salting out procedure for DNA extraction from human nucleated cells. Nucleic Acid Res 16: 1215, 1988.

PASTUCHA D, FILIPČÍKOVÁ R, HORÁKOVÁ D, RADOVÁ L, MARINOV Z, MALINČÍKOVÁ J, KOCVRLICH M, HORÁK S, BEZDIČKOVÁ M, DOBIÁŠ M: The incidence of metabolic syndrome in obese Czech children: the importance of early detection of insulin resistance using homeostatic indexes HOMA-IR and QUICKI. Physiol Res 62: 277-283, 2013.

PETERSON RE, MAES HH, HOLMANS P, SANDERS AR, LEVINSON DF, SHI J, KENDLER KS, GEJMAN PV, WEBB BT: Genetic risk sum score comprised of common polygenic variation is associated with body mass index. Hum Genet 129: 221-230, 2011.

REINEHR T, WOLTERS B, ROTH CL, HINNEY A: FTO gene: association to weight regain after lifestyle intervention in overweight children. Horm Res Paediatr 81: 391-396, 2014.

REITZ C, TOSTO G, MAYEUX R, LUCHSINGER JA; NIA-LOAD/NCRAD FAMILY STUDY GROUP; ALZHEIMER'S DISEASE NEUROIMAGING INITIATIVE: Genetic variants in the Fat and Obesity Associated (FTO) gene and risk of Alzheimer's disease. PLoS One 7: e50354, 2012.

SCHUM J, BLUMENSTOCK G, WEBER K, SCHWEIZER R, PFAFF C, SCHURR N, RANKE MB, BINDER G, EHEHALT S; DISKUS-STUDY GROUP: Variants of the FTO gene in obese children and their impact on body composition and metabolism before and after lifestyle intervention. Exp Clin Endocrinol Diabetes 120: 128-131, 2012.

SCOTT LJ, MOHLKE KL, BONNYCASTLE LL, WILLER CJ, LI Y, DUREN WL, ERDOS MR, STRINGHAM HM, CHINES PS, JACKSON AU, PROKUNINA-OLSSON L, DING CJ, SWIFT AJ, NARISU N, HU T, PRUIM R, XIAO R, LI XY, CONNEELY KN, RIEBOW NL, SPRAU AG, TONG M, WHITE PP, HETRICK KN, BARNHART MW, BARK CW, GOLDSTEIN JL, WATKINS L, XIANG F, SARAMIES J, BUCHANAN TA, WATANABE RM, VALLE TT, KINNUNEN L, ABECASIS GR, PUGH EW, DOHENY KF, BERGMAN RN, TUOMILEHTO J, COLLINS FS, BOEHNKE M: A genome-wide association study of type 2 diabetes in Finns detects multiple susceptibility variants. Science 316: 1341-1345, 2007.

SCUTERI A, SANNA S, CHEN WM, UDA M, ALBAI G, STRAIT J, NAJJAR S, NAGARAJA R, ORRÚ M, USALA G, DEI M, LAI S, MASCHIO A, BUSONERO F, MULAS A, EHRET GB, FINK AA, WEDER AB, COOPER RS, GALAN P, CHAKRAVARTI A, SCHLESSINGER D, CAO A, LAKATTA E, ABECASIS GR: Genome-wide association scan shows genetic variants in the FTO gene are associated with obesity-related traits. PLoS Genet 3: e115, 2007.

SUCHANEK P, LANSKA V, HUBACEK JA: Body composition changes in adult females after lifestyle intervention are influenced by NYD-SP18 variant. Cent Eur J Public Health in press 2015.

TÖNJES A, ZEGGINI E, KOVACS P, BÖTTCHER Y, SCHLEINITZ D, DIETRICH K, MORRIS AP, ENIGK B, RAYNER NW, KORIATH M, ESZLINGER M, KEMPPINEN A, PROKOPENKO I, HOFFMANN K, 
TEUPSER D, THIERY J, KROHN K, MCCARTHY MI, STUMVOLL M: Association of FTO variants with BMI and fat mass in the self-contained population of Sorbs in Germany. Eur J Hum Genet 18: 104-110, 2010.

TUNSTALL-PEDOE H, KUULASMAA K, TOLONEN H, DAVIDSON M, MENDIS S: MONICA Monograph and Multimedia Sourcebook 2003. TUNSTALL-PEDOE H (ed.), World Health Organisation, Geneva, 2003.

VRABLÍK M, DOBIÁŠOVÁ M, ZLATOHLÁVEK L, URBANOVÁ Z, ČEŠKA R: Biomarkers of cardiometabolic risk in obese/overweight children: effect of lifestyle intervention. Physiol Res 63: 743-752, 2014.

WILK JB, LARAMIE JM, LATOURELLE JC, WILLIAMSON S, NAGLE MW, TOBIN JE, FOSTER CL, ECKFELDT JH, PROVINCE MA, BORECKI IB, MYERS RH: NYD-SP18 is associated with obesity in the NHLBI Family Heart Study. Int J Obes (Lond) 32: 930-935, 2008.

WU Q, SAUNDERS RA, SZKUDLAREK-MIKHO M, SERNA IDE L, CHIN KV: The obesity-associated FTO gene is a transcriptional coactivator. Biochem Biophys Res Comm 401: 390-395, 2010.

ZLATOHLAVEK L, VRABLIK M, MOTYKOVA E, CESKA R, VASICKOVA L, DLOUHA D, HUBACEK JA: FTO and MC4R gene variants determine BMI changes in children after intensive lifestyle intervention. Clin Biochem 46: 313-316, 2013. 